\title{
PENGEMBANGAN PERANGKAT PEMBELAJARAN DENGAN MENGGUNAKAN MODEL PEMBELAJARAN SNOWBALL THROWING BERBASIS TUGAS TERSTRUKTUR PADA MATA KULIAH STRUKTUR ALJABAR I
}

\author{
Tri Andari ${ }^{1}$ Restu Lusiana ${ }^{2}$ \\ ${ }^{1}$ Prodi Pendidikan Matematika, FMIPA IKIP PGRI Madiun, Kota Madiun \\ ${ }^{1}$ Prodi Pendidikan Matematika, FMIPA IKIP PGRI Madiun, Kota Madiun
}

\begin{abstract}
ABSTRAK: Penelitian ini bertujuan menghasilkan perangkat pembelajaran yang baik dengan menggunakan model Snowball Throwing Berbasis Tugas Terstruktur pada mata kuliah Struktur Aljabar I. Hal yang melatarbelakangi penelitian ini adalah kenyataan bahwa mata kuliah Struktur Aljabar merupakan salah satu mata kuliah yang memuat konsep konsep yang abstrak, karena sifat dari mata kuliah tersebut seperti itu maka mahasiswa seringkali mendapat kesulitan dalam mempelajarinya. Untuk mengatasi hal tersebut, seorang dosen harus mampu membantu dan mengarahkan mahasiswa agar dapat mempelajari materi-materi pada mata kuliah tersebut menjadi lebih menarik dan bermakna. Pemberian tugas secara terstruktur diharapkan dapat meningkatkan keaktifan mahasiswa sehingga dapat mendorong mahasiswa untuk mempelajari materi-materi tersebut secara terarah. Penelitian pengembangan ini dilakukan menggunakan model pengembangan 4-D Thiagarajan, dkk. Model Thiagarajan terdiri dari 4 tahap yang dikenal dengan model 4-D (four D model). Model pengembangan perangkat pembelajaran pada penelitian ini adalah model Thiagarajan, Semmel, dan Semmel yang dikenal dengan four- $D$ model (model 4-D) yang terdiri dari 4 tahap. Namun, dalam penelitian dimodifikasi menjadi tiga tahap pengembangan perangkat, yaitu tahap pendefinisian, tahap perancangan dan tahap pengembangan. Penelitian dilaksanakan di Prodi Pendidikan Matematika IKIP PGRI Madiun Semester enam. Model pengumpulan data melalui angket dan tes. Perangkat pembelajaran yang dihasilkan: Satuan Acara Perkuliahan (SAP), Lembar Kegiatan Mahasiswa (LKM), dan Tes Hasil Belajar (THB) pada mata kuliah Struktur Aljabar materi Group. Beberapa data yang diperolah pada pelaksanaan ujicoba perangkat pembelajaran meliputi aktivitas mahasiswa, kemampuan dosen mengelola pembelajaran, kemampuan mahasiswa dalam melaksanakan kompetensi guru profesional, tes hasil belajar, dan respon mahasiswa. Perangkat pembelajaran yang telah didapatkan dinyatakan valid oleh para validator dan memenuhi kriteria yaitu aktivitas mahasiswa efektif, kemampuan dosen mengelola pembelajaran baik, kemampuan mahasiswa dalam melaksanakan kompetensi guru profesional baik, tes hasil belajar sensitif, valid, dan reliabel, serta respon mahasiswa positif. Perangkat pembelajaran dengan model Snowball Throwing berbasis tugas terstruktur yang dihasilkan meliputi Satuan Acara Perkuliahan (SAP), Lembar Kegiatan Mahasiswa (LKM), dan Tes Hasil Belajar (THB).
\end{abstract}

Kata Kunci: Pengembangan, Perangkat Pembelajaran, Model Snowball Throwing Berbasis Tugas Terstruktur, Struktur Aljabar I

\section{PENDAHULUAN}

Pendidikan merupakan proses yang sangat menentukan perkembangan individu dan perkembangan masyarakat suatu bangsa. Dalam Pasal 3 UU RI 20/2003 dijelaskan bahwa pendidikan nasional berfungsi untuk mengembangkan kemampuan dan membentuk watak serta peradaban bangsa yang bermartabat dalam rangka mencerdaskan kehidupan bangsa. Pendidikan pada akhirnya harus 
diajukan pada upaya mewujudkan sebuah masyarakat yang ditandai adanya keluhuran budi dalam individu, keadilan dalam negara, dan sebuah kehidupan yang lebih bahagia dari setiap individunya.

Kemampuan dan keterampilan yang dimiliki seseorang tentu sesuai dengan tingkat pendidikan yang dimilikinya. Semakin tinggi pendidikan seseorang, maka diasumsikan semakin tinggi pula pengetahuan, keterampilan, dan kemampuannya. Hal ini menggambarkan bahwa fungsi pendidikan dapat meningkatkan kesejahteraan, karena orang yang berpendidikan dapat terhindar dari kebodohan maupun kemiskinan. Dengan demikian dapat ditegaskan bahwa fungsi pendidikan adalah membimbing anak ke arah suatu tujuan yang dinilai tinggi. Pendidikan yang baik adalah usaha yang berhasil membawa semua anak didik kepada tujuan itu.

Pendidik yang berhubungan langsung dengan peserta didik adalah guru. Guru sangat memegang peranan penting dalam menyiapkan peserta didik menyongsong masa depannya. Etos kerja guru akan menentukan keberhasilan peserta didik dan kesiapan generasi muda untuk bersaing dengan bangsa lain. Profesi guru adalah unik karena mereka memiliki peranan antara lain sebagai pengajar, pandu, menjadi penghubung dalam meneruskan cita dan nilai budaya bangsa. Untuk dapat berkarya, kemampuan guru dalam berkreasi mengajar sangat diperlukan. Kompetensi guru dalam hal penguasaan materi, pengelolaan kelas, penciptaan suasana belajar yang meyenagkan bagi peserta didiknya, serta kemampuan guru dalam menilai prestasi mahasiswanya merupakan syarat mutlak untuk mencapai keberhasilan proses belajar mengajar.

PASAL 28 ayat 3 Peraturan Pemerintah No.19 Tahun 2005 tentang Standar Nasional Pendidikan secara tegas dinyatakan bahwa ada empat kompetensi yang harus dimiliki guru sebagai agen pembelajaran (dalam Khoirida: 2010). Keempat kompetensi itu adalah kompetensi pedagogik, kompetensi kepribadian, kompetensi professional dan kompetensi sosial. Namun beberapa fakta di lapangan menunjukkan bahwa para mahasiswa calon guru ketika terjun ke lapangan (PPL) masih belum mampu menguasai materi yang diajarkan dengan baik. Selain itu, penguasaan terhadap model atau teknik penyampaian materi juga kurang. Hal ini menunjukkan bahwa kompetensi yang dimiliki masih kurang.

Untuk mengatasi beberapa masalah tersebut, salah satunya diterapkan suatu model pembelajaran Snowball Throwing 
sebagai alternatif, model Snowball Throwing merupakan salah satu cara untuk menarik minat mahasiswa dalam mengikuti dan memahami materi. Dalam pembelajaran dengan menggunakan model Snowball Throwing akan diawali dengan pembentukan kelompok yang diwakili ketua kelompok untuk mendapat tugas dari guru kemudian masing-masing mahasiswa membuat pertanyaan yang dibentuk seperti bola (kertas pertanyaan) lalu dilempar ke mahasiswa lain yang masingmasing mahasiswa menjawab pertanyaan dari bola yang diperoleh (Kisworo, 2008:11) dalam (mukhtar, 2010). Kegiatan melempar bola pertanyaan ini akan membuat kelompok menjadi dinamis, karena kegiatan mahasiswa tidak hanya berpikir, menulis, bartanya, atau berbicara. Akan tetapi mereka juga melakukan aktivitas fisik yaitu menggulung kertas dan melemparkannya pada mahasiswa lain. Dengan demikian, tiap anggota kelompok akan mempersiapkan diri karena pada gilirannya mereka harus menjawab pertanyaan dari temannya yang terdapat dalam bola kertas.

Mata kuliah Struktur Aljabar merupakan salah satu mata kuliah yang memuat konsep-konsep yang abstrak, karena sifat dari mata kuliah tersebut seperti itu maka mahasiswa seringkali mendapat kesulitan dalam mempelajarinya.
Untuk mengatasi hal tersebut, seorang dosen harus mampu membantu dan mengarahkan mahasiswa supaya dapat mempelajari materi-materi pada mata kuliah tersebut menjadi lebih menarik dan bermakna. Penggunaan model Snowball Throwing merupakan salah satu cara untuk menarik minat mahasiswa dalam mengikuti dan memahami materi struktur aljabar, karena dalam model pembelajaran ini melatih mahasiswa untuk lebih tanggap menerima pesan dari orang lain, dan menyampaikan pesan tersebut pada temannya pada satu kelompok. Selain itu pemberian tugas yang terstruktur diharapkan dapat mengatasi permasalahan tersebut dan dapat mendorong mahasiswa untuk mempelajari materi-materi tersebut secara terarah. Penggunaan kedua media pembelajaran tersebut diharapkan dapat memotivasi mahasiswa supaya lebih kreatif dalam memecahkan masalah, mampu berkomunikasi secara matematik, menyajikan matematik dengan penyajian yang beragam, mengaitkan suatu konsep dengan konsep yang lain ataupun dengan kehidupan nyata, serta mampu bernalar secara logis dan sistematis dalam perkuliahan Struktur Aljabar I.

Namun demikian berdasarkan pengamatan peneliti, sampai saat ini terutama di tempat peneliti 
mengajar belum tersusun suatu bahan ajar yang dapat dijadikan panduan mengajar mata kuliah Struktur Aljabar I khususnya pada materi Group dengan menggunakan model Snowball Throwing, ataupun bahan ajar yang dapat memandu mahasiswa secara terstruktur. Melalui model pengembangan pada penelitian ini akan disusun dan dikembangkan bahan ajar yang menggunakan model Snowball Throwing dan tugas terstruktur.

\section{METODE PENELITIAN}

Desain penelitian yang digunakan merupakan penelitian pengembangan (developmental research). Penelitian pengembangan dilakukan untuk mengembangkan perangkat pembelajaran pada mata kuliah Struktur Aljabar. Rancangan penelitian uji coba berbentuk One Group Pretest-Posttest Design sebagaimana disajikan pada Tabel 1 berikut.

Tabel 1 Rancangan Penelitian Ujicoba

\begin{tabular}{|c|c|c|c|}
\hline Kelas & Tes Awal & Perlakuan & Tes Akhir \\
\hline Eksperimen & $\mathrm{T}_{\mathrm{aw}}$ & $\mathrm{X}$ & $\mathrm{T}_{\mathrm{ak}}$ \\
\hline
\end{tabular}

Keterangan:

$\mathrm{T}_{\mathrm{aw}}$ : tes awal, tes sebelum perlakuan

$\mathrm{X}$ : pembelajaran dengan model Snowball Throwing Berbasis Tugas Terstruktur.

$\mathrm{T}_{\mathrm{ak}} \quad$ : tes akhir, tes setelah perlakuan

Penelitian ini dilaksanakan pada mahasiswa semester VI Prodi Pendidikan Matematika FPMIPA IKIP PGRI Madiun. Subyek penelitian ujicoba adalah mahasiswa kelas VI A semester VI Prodi Pendidikan Matematika FPMIPA IKIP PGRI Madiun. Kelas ini dipilih secara acak karena mahasiswa di setiap kelas yang ada di Program Studi Pendidikan Matematika FPMIPA IKIP PGRI Madiun memiliki kemampuan yang beragam.
Model pengembangan perangkat pembelajaran pada penelitian ini adalah model Thiagarajan, Semmel, dan Semmel yang dikenal dengan four-D model (model 4-D). Model Thiagarajan terdiri dari 4 tahap yang dikenal dengan model 4-D (four D model). Keempat tahap tersebut adalah tahap pendefinisian (define), tahap perancangan (design), tahap pengembangan (development), dan tahap penyebaran (disseminate). Uraian keempat tahap beserta 
komponen-komponen

Thiagarajan sebagai berikut:

\section{Tahap Pendefinisian (Define)}

Tahap ini bertujuan untuk menetapkan dan mendefinisikan kebutuhan-kebutuhan pembelajaran dengan menganalisis tujuan dan batasan materi. Tahap pendefinisian terdiri dari 5 langkah yaitu analisis awal-akhir, analisis mahasiswa, analisis konsep, analisis tugas dan spesifikasi tujuan pembelajaran..

2. Tahap Perancangan (Design)

Tahap ini bertujuan untuk menghasilkan rancangan perangkat pembelajaran awal, yaitu rancangan perangkat pembelajaran yang sesuai dengan model Snowball Throwing berbasis tugas terstruktur. Tahap ini dimulai setalah ditetapkan tujuan pembelajaran khusus. Tahap perancangan terdiri dari empat langkah pokok, yaitu penyusunan tes, pemilihan media, pemilihan format, dan perancangan awal (desain awal). Untuk keperluan penelitian, diperlukan lembar pengamatan

b. Pada model 4-D, istilah analisis konsep diganti dengan analisis materi. Hal ini karena materi yang terdapat pada pembelajaran tidak hanya memuat konsep materi saja, tetapi juga memuat prinsip, relasi, dan operasi. pengelolaan pembelajaran, lembar pengamatan aktivitas mahasiswa, dan angket respon mahasiswa.

3. Tahap Pengembangan (Develop) Tahap ini bertujuan untuk menghasilkan draft perangkat pembelajaran yang telah direvisi berdasarkan masukan para ahli dan data yang diperoleh dari uji coba (Draft final). Draft perangkat pembelajaran ini meliputi: Satuan Acara Perkuliahan (SAP), Lembar Kegiatan Mahasiswa (LKM) yang sesuai dengan pembelajaran diskusi kelas berbasis diskusi kelompok intuitif, dan Tes Hasil Belajar (THB).

Dalam hal ini, peneliti juga melakukan modifikasi, yaitu:

a. Pada model 4-D, analisis konsep dan analisis tugas dilakukan secara paralel. Sedangkan pada penelitian ini, analisis konsep dan analisis tugas dilakukan secara berurutan. Hal ini dilakukan karena materi dalam mata kuliah Stuktur Aljabar urutan tugas bergantung pada urutan materi/konsep.

Instrumen pengumpulan data yang digunakan dalam penelitian ini adalah lembar validasi, lembar validasi keterbacaan (yang meliputi SAP, LKM, dan THB), lembar Observasi/ Pengamatan (lembar 
pengamatan pengelolaan pembelajaran, lembar pengamatan aktivitas mahasiswa, lembar pengamatan kemampuan mahasiswa dalam memahami materi, angket respon mahasiswa, dan tes hasil belajar).

Analisis data yang digunakan dalam penelitian ini adalah analisis data hasil validasi perangkat pembelajaran, analisis data hasil validasi keterbacaan, analisis data observasi (yang meliputi data kemampuan dosen dalam mengelola pembelajaran, data aktivitas mahasiswa selama pembelajaran, dan data kemampuan ini: mahasiswa dalam memahami materi, analisis data respon mahasiswa, dan analisis data tes hasil belajar)

\section{HASIL PENELITIAN DAN PEMBAHASAN}

Pada pembahasan hasil penelitian ini dibahas pencapaian kriteria perangkat pembelajaran dengan model Snowball Throwing berbasis tugas terstruktur. Pencapaian kriteria perangkat pembelajaran dengan model Snowball Throwing berbasis tugas terstruktur dapat dilihat pada tabel 2

berikut

\section{Tabel 2 Pencapaian Kriteria Perangkat Pembelajaran Dengan Model Snowball Throwing Berbasis Tugas Terstruktur}

\begin{tabular}{|r|l|c|}
\hline No. & \multicolumn{1}{|c|}{ Aspek Kategori } & Keterangan \\
\hline 1 & Aktivitas mahasiswa & Efektif \\
\hline 2 & $\begin{array}{l}\text { Kemampuan dosen dalam mengelola } \\
\text { pembelajaran }\end{array}$ & Baik \\
\hline 3 & $\begin{array}{l}\text { Kemampuan mahasiswa dalam memahami } \\
\text { materi }\end{array}$ & Baik \\
\hline 4 & Tes hasil belajar & Positif \\
\hline 5 & Respon mahasiswa & \\
\hline
\end{tabular}

Tabel 2 menunjukkan bahwa berdasarkan hasil penelitian didapatkan perangkat pembelajaran dengan model Snowball Throwing berbasis tugas terstruktur pada materi Group dengan menggunakan model 4-D yang telah dimodifikasi. Perangkat pembelajaran yang dihasilkan pada penelitian yang dilakukan di kelas VI F Program Studi Pendidikan Matematika IKIP PGRI Madiun meliputi Satuan Acara Perkuliahan (SAP), Lembar Kegiatan Mahasiswa (LKM), dan Tes Hasil Belajar (THB). 


\section{KESIMPULAN DAN SARAN}

Kesimpulan yang didapatkan berdasarkan hasil penelitian adalah perangkat pembelajaran dengan model Snowball Throwing berbasis tugas terstruktur dikembangkan dengan menggunakan model pengembangan 4-D yang dimodifikasi. Pengembangan perangkat pembelajaran pada penelitian ini dilakukan sampai tahap ketiga, yaitu pendefinisian (define), perancangan (design), dan pengembangan (develop). Perangkat pembelajaran Snowball Throwing berbasis tugas terstruktur yang baik telah didapatkan dengan menggunakan model 4-D ini. Hal ini karena perangkat pembelajaran yang telah didapatkan dinyatakan valid oleh para validator dan memenuhi kriteria:

1. Aktivitas mahasiswa efektif

2. Kemampuan dosen mengelola pembelajaran baik

3. Kemampuan mahasiswa dalam memahami materi baik

4. Tes hasil belajar sensitif, valid, dan reliabel

Perangkat pembelajaran dengan model Snowball Throwing berbasis tugas terstruktur yang dihasilkan meliputi Satuan Acara Perkuliahan (SAP), Lembar Kegiatan Mahasiswa (LKM), dan Tes Hasil Belajar (THB).
Saran yang dikemukakan berdasarkan data pada tes ujicoba perangkat pembelajaran pada penelitian ini masih perlu diujicobakan di kelas lain dengan berbagai kondisi yang berbeda agar diperoleh perangkat pembelajaran yang lebih berkualitas.

\section{DAFTAR PUSTAKA}

Arikunto, Suharsimi. 2003. DasarDasar Evaluasi Pendidikan. Jakarta: Bumi Aksara

Dara, Fornichly Revi. 2009. Pembelajaran Matematika Realistik untuk Materi Balok dan Kubus di Kelas VII SMP Negeri 1 Nabire. Tesis. PPs Unesa Surabaya

Fithriani, Sitti Saleh. 2005. Pendekatan Problem Posing Berlatar Pembelajaran Kooperatif 2w3e56y8i90untuk Topik Sudut di Kelas VII SMP Muh Limbung. Tesis. PPs Unesa Surabaya

Herman Hudojo. 2005. Pengembangan Kurikulum dan Pembelajaran Matematika.

Cetakan I. Malang : Universitas Negeri Malang (UM Press)

$\begin{array}{cr}\text { Karim, Abdul. } & 2003 . \\ \text { Pengembangan } & \text { Perangkat } \\ \text { Pembelajaran } & \text { Pokok Bahasan } \\ \text { Kubus dan Balok Kelas } 1\end{array}$


SLTP Model Kooperatif Tipe STAD dengan Laboratorium Mini. Tesis. PPs Unesa Surabaya

Khoirida

Alfu. 2010.

Pengembangan Perangkat

Pembelajaran Matematika

melalui Pendekatan Problem

Based Learning pada materi Segiempat mahasiswa Kelas 7. Pasca Sarjana Universitas Negeri Semarang (http://jahidinjayawinata61.wor dpress.com/ diakses tanggal 4 Maret 2012).

Monks, Knoers, Rahayu Haditono, Siti,. 2004. Psikologi Perkembangan. Yogyakarta: Gajah Mada University Press.

Mukhtar . 2010 .Penerapan Model Pembelajaran Snowball Throwing Dengan Penilaian Portofolio Dalam Upaya Untuk Meningkatkan Pemahaman Materi Segitiga Mahasiswa Kelas VII A SMP Islam 02 Pujon Tahun Pelajaran 2007/2008.

(http://mukhtaribenk.blogspot.c om) diakses tanggal 5 Maret 2013.

Mustangin. 2002. Dasar-Dasar Pembelajaran Matematika. Malang: UNISMA.

Nursalim, Mochamad dkk. 2007. Psikologi Pendidikan.
Surabaya: Unesa University Press

Sanjaya, Wina. 2006. Strategi Pembelajaran Berorientasi Standar Proses Pendidikan. Jakarta: Kencana Prenada Media Group.

Slameto. (2002). Belajar dan Faktor-faktor Yang Mempengaruhi. Jakarta: Rineka Cipta.

Sudjana, Nana. 2009. Penilaian Hasil Proses Belajar Mengajar. Bandung: PT Remaja Rosdakarya

Syaiful Sagala. 2005. Konsep dan Makna Pembelajaran. Bandung: CV. ALFABETA.

Thiagarajan, S., Semmel, D. S. dan Semmel, M. I. 1974. Instructional Development for Training Teachers of Exceptional Children. Minnesota: University of Minnesota

Trianto. 2009. Mendesain Model Pembelajaran Inovatif Progresif. Jakarta: Kencana Prenada Media Group

Undang-Undang Republik IndonesiaNo. 20 Tahun 2003 tentang Sistem Pendidikan Nasional. Jakarta: Depdiknas 